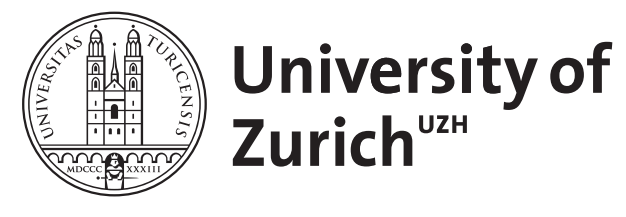

\title{
Parkinson's disease: molecular risk factors
}

\author{
Grünblatt, Edna
}

\begin{abstract}
Parkinson's disease (PD) is a progressive neurodegenerative disorder second only to Alzheimer's disease. Diagnosis remains clinical, based on phenotypic patterns. In the last decade many attempts to develop early differential pre-clinical markers have been reported. In this presentation, the molecular risk factors that may link between the etiopathogenesis leading to PD and peripheral markers will be discussed. Genetic variation known to be involved in familial forms of PD will be shown to be linked to sporadic cases, as for example leucine-rich repeat kinase 2 (LRRK2) that was found to regulate microRNA-mediated translation regulation. In addition postmortem microarray findings of transcription alterations will be compared to the peripheral findings of mRNA profiles. Molecular processes involved in ubiquitination and proteasome, autophagy, mitochondrial dysfunction and the nicotinic and adenosine A2 protection will be discussed. The question of what time-point should be used measuring the different markers and the course of the disease considered, and the future possibilities in exploring these techniques will be debated.
\end{abstract}

DOI: https://doi.org/10.1016/S1353-8020(11)70016-5

Posted at the Zurich Open Repository and Archive, University of Zurich ZORA URL: https://doi.org/10.5167/uzh-61129

Journal Article

Accepted Version

Originally published at:

Grünblatt, Edna (2012). Parkinson's disease: molecular risk factors. Parkinsonism Related Disorders, 18(Supp 1):S45-S48.

DOI: https://doi.org/10.1016/S1353-8020(11)70016-5 


\section{Parkinson's disease: Molecular risk factors}

\section{Edna Grünblatt}

Hospital of Child and Adolescent Psychiatry, University of Zurich, Neumuensterallee 9, 8032 Zurich, Switzerland

\section{Page no. 14}

Abstract: 161 words

Text: 1733 Words Table: 1

References: 19

Key Words: Parkinson's disease, transcription, RNA, diagnose, marker, blood, postmortem

PL02 Hirotaro Narabayashi Symposium: From Pathology to Diagnosis

Chairpersons: Shengdi Chen China and Ronald F. Pfeiffer USA

$\bowtie$ All correspondence to PD Dr. Edna Grünblatt:

Hospital of Child and Adolescent Psychiatry, University of Zurich, Neumünsterallee 9, $\mathrm{CH}-8008$ Zurich, Switzerland

Tel: +41-44-578 6071

Fax: +41-44-578 6081

E-mail: edna.gruenblatt@kjpdzh.ch 


\section{Abstract}

Parkinson's disease (PD) is a progressive neurodegenerative disorder second only to Alzheimer's disease. Diagnosis remains clinical, based on phenotypic patterns. In the last decade many attempts to develop early differential pre-clinical markers have been reported. In this presentation, the molecular risk factors that may link between the etiopathogenesis leading to PD and peripheral markers will be discussed. Genetic variation known to be involved in familial forms of PD will be shown to be linked to sporadic cases, as for example leucine-rich repeat kinase 2 (LRRK2) that was found to regulate microRNA-mediated translation regulation. In addition postmortem microarray findings of transcription alterations will be compared to the peripheral findings of mRNA profiles. Molecular processes involved in ubiquitination and proteasome, autophagy, mitochondrial dysfunction and the nicotinic and adenosine $\mathrm{A} 2$ protection will be discussed. The question of what time-point should be used measuring the different markers and the course of the disease considered, and the future possibilities in exploring these techniques will be debated. 


\section{Introduction}

Parkinson's disease (PD) is a progressive neurodegenerative disorder second only to Alzheimer's disease. Since the fact that diagnosis remains clinical based on the presence of a combination of cardinal signs, including rest tremor, bradykinesia, rigidity, and loss of postural reflexes, the diagnosis will most often be made after more than $70-80 \%$ of the dopaminergic neurons have degenerated [1]. There is wide agreement that a preclinical approach detecting at-risk PD subjects would enable earlier preventive therapy that might slow down or even stop the neurodegeneration. In this review the molecular risk factors will be described, beginning with familial genetic findings and continuing with transcription profile studies in the central nervous system (CNS)that have been studied postmortem to the new findings of transcription factors, alterations found in peripheral blood samples, which link some again to familial genetic forms.

Since the discovery of the first disease-causing mutation in the $\alpha$-synuclein gene (SNCA/ PARK1/4), a number of genes and loci have been implicated in PD denoted as PARK1 to 14 . Those genes harboring mutations that cause late-onset dominantly inherited PD include SNCA and leucine-rich repeat kinase 2 (LRRK2/PARK8), whereas early-onset recessive parkinsonism is associated with homozygous and compound heterozygous mutations in parkin (PRKN/PARK2), Pten-induced kinase 1 (PINK1/PARK6) and Oncogene DJ-1 (DJ-1/PARK7) [2]. Despite their importance in identifying key molecules in the pathogenesis of PD, these genetic mutations remain relatively rare (less than $5 \%$ ). On the other hand, association studies in sporadic PD have found that similar genes such as SNCA polymorphism, as well as microtubuleassociated protein tau/saitohin (MAPT/STH), glucoberebrosidase (GBA) and LRRK2 are associated with the risk of PD, but as the highest odds ratio after meta-analysis reaches 3.4 it must still be validated in larger and diverse population [3]. 
As an additional approach to finding new candidate molecules involved in the etiopathogenesis of PD, many gene expression studies have been conducted on postmortem brain tissue, especially on the substantia nigra (SN), the affected brain region (for review see Table 1 ).

Studying the various reports and different brain regions reveals the involvement of protein metabolism and handling (e.g. aggregation and ubiquitination processes, proteasome and vesicular trafficking), the energy pathway including the mitochondria, the response to stress (e.g. heat shock proteins and their chaperones), the autophagy processes, inflammation, adenosine receptors (caffeine) as well as oxidative metabolism (Table 1). In addition, in many of the postmortem studies found a link between familial to sporadic PD, with the finding of alterations in the transcription of $S N C A[6,8,9,12]$, which may point to a common neurodegeneration mechanism in both cases. Similarly, UCHL-1 (PARK5) and DJ-1 (PARK7) mRNA were found to alter in sporadic PD [4-6, 10].

As the availability of postmortem brain tissue is limited, as well as the need for early diagnosis research has been directed to the periphery, with the aim of finding similar alterations there as in the CNS. Indeed, such alterations have been confirmed [6]. As in the postmortem brain studies, many of the molecular pathways discovered in the first approach have also been found in the periphery (Table 1). TRIM24 mRNA was found to alter its expression in peripheral blood both in sporadic PD as well as in carriers of the PARK2 or LRRK2 mutations [19]. TRIM24 is involved in the transcription control of some nuclear receptors, but was also found to be involved in the control of apoptosis and autophagia mechanisms. Therefore it could be hypothesized that this marker may point to the common mechanism involving autophagy and oxidative stress leading to apoptosis. In PD carriers of the LRRK2 mutation gene expression profiles in blood samples revealed the involvement of the 
ubiquitin-proteasome system [18]. Again, also in this study one can conclude similar molecular pathways of the protein metabolism to be involved both in sporadic and familial PD. In a familial PD study with duplications of the SNCA gene it was shown that this duplication directly influences the expression of the SNCA mRNA in blood [18]. This finding enhances the notion of the involvement of SNCA in the etiopathology of PD.

From the current findings, it could be concluded that peripheral molecular markers can mirror the disease processes and may be even detect progression of the disease. Of course, the path is still long, in order to reach the best set of markers that will best provide early differential diagnosis for PD. But such future perspectives seem to be nearing. For such an aim, there is a need for a longitudinal large scale international study, in which at-risk subjects will be followed up for their progression to PD phenotypes while in parallel different markers will be collected, as for example peripheral blood samples (for DNA/ genotypes, RNA/ transcriptomics and proteins/ proteomics), imaging data as well as later on for conformational diagnosis, postmortem brain tissue should be collected when possible. Of course, since the data produced from such large gene wide analysis is huge and quite complicated there is need for interdisciplinary work field including molecular biologists, imaging experts, clinicians and bioinformatics specialist who can work this mass of information into comprehensive data. Such an approach could unravel new and common mechanism both involved in familial and sporadic PD that may lead to some new models for the neuropathophysiology causing this neurodegeneration. Still the main question of the time point, when one should start the diagnosis for PD, is not yet answered. The main reason to this is the fact that therapy should be available in order to slow-down or stop the progress of the disease. But also ethical aspects are involved. 


\section{References (Max 20)}

[1] Wu Y, Le W and Jankovic J Preclinical biomarkers of Parkinson disease Arch Neurol 2011; 68: 22-30.

[2] Zheng B, Liao Z, Locascio JJ, Lesniak KA, Roderick SS, Watt ML, et al. PGC1alpha, a potential therapeutic target for early intervention in Parkinson's disease Sci Transl Med 2010; 2: 52ra73.

[3] Lill C, Roehr J, McQueen M, Kavvoura F, Bagade S, Schjeide B, et al. The PDGene Database 5 September 2011 http://www.pdgene.org/

[4] Mandel S, Amit T, Kalfon L and Youdim MB Applying transcriptomic and proteomic knowledge to Parkinson's disease drug discovery Exp. Opin. Drug Discov. 2007; 2: 1225-40.

[5] Papapetropoulos S and McCorquodale D Gene-expression profiling in Parkinson's disease: discovery of valid biomarkers, molecular targets and biochemical pathways Future Neurology 2007; 2: 29-38.

[6] Grünblatt E, Zehetmayer S, Jacob CP, Muller T, Jost WH and Riederer P Pilot study: peripheral biomarkers for diagnosing sporadic Parkinson's disease J Neural Transm 2010.

[7] Lu L, Neff F, Alvarez-Fischer D, Henze C, Xie Y, Oertel WH, et al. Gene expression profiling of Lewy body-bearing neurons in Parkinson's disease Exp Neurol 2005; 195: 27-39.

[8] Fuchs J, Tichopad A, Golub Y, Munz M, Schweitzer KJ, Wolf B, et al. Genetic variability in the SNCA gene influences alpha-synuclein levels in the blood and brain FASEB J 2008; 22: 1327-34.

[9] Shehadeh L, Mitsi G, Adi N, Bishopric N and Papapetropoulos S Expression of Lewy body protein septin 4 in postmortem brain of Parkinson's disease and control subjects Mov Disord 2009; 24: 204-10. 
[10] Kumaran R, Vandrovcova J, Luk C, Sharma S, Renton A, Wood NW, et al. Differential DJ-1 gene expression in Parkinson's disease Neurobiol Dis 2009; 36: 393-400.

[11] Varani K, Vincenzi F, Tosi A, Gessi S, Casetta I, Granieri G, et al. A2A adenosine receptor over_expression and functionality, as well as TNF-alpha levels, correlate with motor symptoms in Parkinson's disease FASEB J 2010; 24: 587-98.

[12] Shehadeh LA, Yu K, Wang L, Guevara A, Singer C, Vance J, et al. SRRM2, a potential blood biomarker revealing high alternative splicing in Parkinson's disease PLoS One 2010; 5: e9104.

[13] Lanoue AC, Dumitriu A, Myers RH and Soghomonian JJ Decreased glutamic acid decarboxylase mRNA expression in prefrontal cortex in Parkinson's disease Exp Neurol 2010; 226: 207-17.

[14] Nagai Y, Ueno S, Saeki Y, Soga F, Hirano M and Yanagihara T Decrease of the D3 dopamine receptor mRNA expression in lymphocytes from patients with Parkinson's disease Neurology 1996; 46: 791-5.

[15] Kawaguchi N, Yamada T, Takahashi $M$ and Hattori $T$ Expression of $M x A$ mRNA in peripheral blood mononuclear cells in Parkinson's disease Parkinsonism Relat Disord 1999; 5: 43-7.

[16] Soreq L, Israel Z, Bergman $\mathrm{H}$ and Soreq $\mathrm{H}$ Advanced microarray analysis highlights modified neuro-immune signaling in nucleated blood cells from Parkinson's disease patients J Neuroimmunol 2008; 201-202: 227-36.

[17] Reale M, larlori C, Thomas A, Gambi D, Perfetti B, Di Nicola M, et al. Peripheral cytokines profile in Parkinson's disease Brain Behav Immun 2009; 23: 5563. 
[18] Mutez E, Lepretre F, Le Rhun E, Larvor L, Duflot A, Mouroux V, et al. SNCA locus duplication carriers: from genetics to Parkinson disease phenotypes Hum Mutat 2011; 32: E2079-90.

[19] Aguiar P and Severino P Biomarkers in Parkinson disease: global gene expression analysis in peripheral blood from patients with and without mutations in PARK2 and PARK8 einstein 2010; 8: 293-7. 
Table 1: Summary of transcription (RNA) profiles in postmortem brain tissue and peripheral blood samples from Parkinson's disease subjects (modified from [4, 5])

\begin{tabular}{|c|c|c|c|c|c|}
\hline Samples origin & $\begin{array}{l}\text { Region /cell } \\
\text { type }\end{array}$ & $\begin{array}{l}\text { Method of } \\
\text { measurements }\end{array}$ & Genes found & $\begin{array}{l}\text { Familial / } \\
\text { Sporadic PD / } \\
\text { HC }\end{array}$ & $\begin{array}{l}\text { Reference / the } \\
\text { research group }\end{array}$ \\
\hline \multirow[t]{6}{*}{ CNS } & SN & $\begin{array}{l}\text { Affymetrix HG- } \\
\text { Focus array }\end{array}$ & $\begin{array}{l}\text { PSMA2-5 } \\
\text { HIP2 } \\
\text { SKP1A } \\
\text { GBE1 } \\
\text { UQCRC2 } \\
\text { ALDH1A1 } \\
\text { LAMB2 } \\
\text { DNAJB5 (Hsp40) } \\
\text { HSPA8 }\end{array}$ & Sporadic & $\begin{array}{l}6] \\
\text { Grünblatt and } \\
\text { colleagues } 2004\end{array}$ \\
\hline & $\begin{array}{l}\text { SN, Putamen, } \\
\text { BA9 }\end{array}$ & $\begin{array}{l}\text { Affymetrix U133A } \\
\text { GeneChip }\end{array}$ & $\begin{array}{l}\text { NEFL } \\
\text { HSPB1 } \\
\text { FGF13 } \\
\text { NSF } \\
\text { SNAP25 } \\
\text { SYT1 }\end{array}$ & Sporadic & $\begin{array}{l}{[5]} \\
\text { Zhang and } \\
\text { colleagues } 2005\end{array}$ \\
\hline & SN & $\begin{array}{l}\text { Affymetrix U133A } \\
\text { GeneChip }\end{array}$ & $\begin{array}{l}\text { HSPA1A-B } \\
\text { SYT1 } \\
\text { UBE1 }\end{array}$ & Sporadic & $\begin{array}{l}5] \\
\text { Hauser and } \\
\text { colleagues } 2005\end{array}$ \\
\hline & $\begin{array}{l}\text { LB-containing DA } \\
\text { neurons vs. non- } \\
\text { LB-containing DA } \\
\text { neurons }\end{array}$ & RNA fingerprinting & $\begin{array}{l}\text { STCH (Hsp70) } \\
\text { USP8 } \\
\text { ANP32B }\end{array}$ & & [7] \\
\hline & $\begin{array}{l}\text { SN medial / } \\
\text { lateral }\end{array}$ & $\begin{array}{l}\text { Affymetrix U133A \& } \\
\text { B GeneChip }\end{array}$ & $\begin{array}{l}\text { NEFL } \\
\text { HIP2 } \\
\text { HSPB1 } \\
\text { UCHL-1 } \\
\text { GBE1 } \\
\text { ALDH1A1 } \\
\text { FGF13 } \\
\text { NSF } \\
\text { SNAP25 }\end{array}$ & Sporadic & $\begin{array}{l}{[4,5]} \\
\text { Moran and } \\
\text { colleagues } 2006 \\
\text { Duke and } \\
\text { colleagues } 2006\end{array}$ \\
\hline & SN, Striatum & CodeLink Human & UCHL-1 & Sporadic & [5] \\
\hline
\end{tabular}




\begin{tabular}{|c|c|c|c|c|c|}
\hline Samples origin & $\begin{array}{l}\text { Region /cell } \\
\text { type }\end{array}$ & $\begin{array}{l}\text { Method of } \\
\text { measurements }\end{array}$ & Genes found & $\begin{array}{l}\text { Familial / } \\
\text { Sporadic PD / } \\
\text { HC }\end{array}$ & $\begin{array}{l}\text { Reference / the } \\
\text { research group }\end{array}$ \\
\hline & & $\begin{array}{lll}\text { UniSet } & 20 \quad \mathrm{~K} \\
\text { bioarray } & & \end{array}$ & $\begin{array}{l}\text { FGF13 } \\
\text { NSF } \\
\text { SYN1-2 } \\
\text { SYT1 } \\
\text { STX1A }\end{array}$ & & $\begin{array}{l}\text { Miller and } \\
\text { colleagues } 2006\end{array}$ \\
\hline & $\begin{array}{l}\text { Putamen, } \\
\text { occipital cortex, } \\
\text { cerebellar } \\
\text { hemispheres }\end{array}$ & $\begin{array}{ll}\text { Affymetrix } & \text { U133A } \\
\text { GeneChip } & \end{array}$ & $\begin{array}{l}\text { NPY } \\
\text { HTR2C } \\
\text { SYT1 }\end{array}$ & Sporadic & $\begin{array}{l}5] \\
\text { Vogt and } \\
\text { colleagues } 2006\end{array}$ \\
\hline & $\begin{array}{l}\text { SN, vetral } \\
\text { tegmental area, } \\
\text { perirhinal corte } \\
\text { (BA35), insular } \\
\text { cortex, } \\
\text { amygdale, } \\
\text { nucleus basalis, } \\
\text { caudate, } \\
\text { putamen, } \\
\text { nucleus } \\
\text { accumbens, } \\
\text { golobus pallidus, } \\
\text { mediodorsal } \\
\text { thalamus, } \\
\text { pulvinar, } \\
\text { subthalamic } \\
\text { nucleus, dorsal } \\
\text { nucleus of the } \\
\text { vagus nerve, } \\
\text { cerebellar } \\
\text { hemisphere, } \\
\text { anterior } \\
\text { cerebellar } \\
\text { vermis, dorsal } \\
\text { ceruleus, }\end{array}$ & $\begin{array}{l}\text { Affymetrix Human } \\
\text { Genome U133 Plus } \\
\text { 2.0 GeneChip }\end{array}$ & $\begin{array}{l}\text { MRPS6 } \\
\text { STIP }\end{array}$ & Sporadic & $\begin{array}{l}\text { [5] } \\
\text { Papapetropoulos } \\
\text { and colleagues } \\
2006\end{array}$ \\
\hline
\end{tabular}




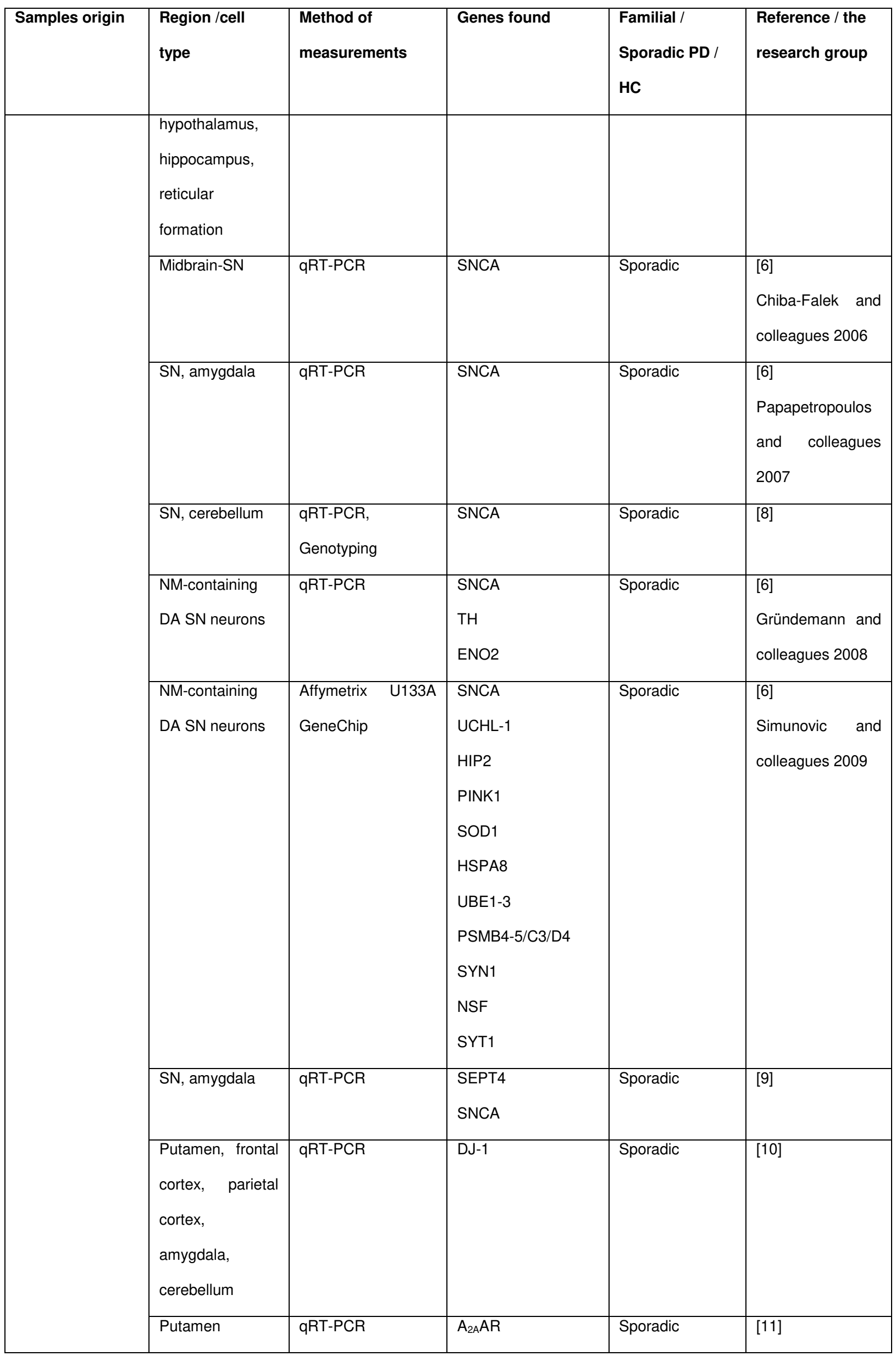




\begin{tabular}{|c|c|c|c|c|c|}
\hline Samples origin & $\begin{array}{l}\text { Region /cell } \\
\text { type }\end{array}$ & $\begin{array}{l}\text { Method of } \\
\text { measurements }\end{array}$ & Genes found & $\begin{array}{l}\text { Familial / } \\
\text { Sporadic PD / } \\
\text { HC }\end{array}$ & $\begin{array}{l}\text { Reference / the } \\
\text { research group }\end{array}$ \\
\hline & SN, amygdala & qRT-PCR & $\begin{array}{l}\text { SEPT4 } \\
\text { SNCA }\end{array}$ & Sporadic & [12] \\
\hline & BA9 & $\begin{array}{l}\text { In-situ hybridization; } \\
\text { One-Color Agilent } \\
\text { 60-mer Whole } \\
\text { Human Genome } \\
\text { Microarray }\end{array}$ & GAD76 & Sporadic & [13] \\
\hline & SN & $\begin{array}{l}\text { genome-wide meta- } \\
\text { analysis }\end{array}$ & PGC-1alpha & Sporadic & [2] \\
\hline \multirow[t]{8}{*}{ Peripheral blood } & lymphocytes & $\begin{array}{l}\text { Semi-quantitative } \\
\text { PCR }\end{array}$ & D3R & Sporadic & [14] \\
\hline & PBMC & $\begin{array}{l}\text { Semi-quantitative } \\
\text { PCR }\end{array}$ & $\mathrm{MxA}$ & Sporadic & [15] \\
\hline & Whole blood & $\begin{array}{l}\text { Affymetrix U133A } \\
\text { GeneChip }\end{array}$ & $\begin{array}{l}\text { ST13 } \\
\text { HIP2 } \\
\text { CLTB }\end{array}$ & Sporadic & $\begin{array}{l}\text { [2] } \\
\text { Scherzer and } \\
\text { colleagues } 2007\end{array}$ \\
\hline & Whole blood & $\begin{array}{l}\text { Affymetrix U133A } \\
\text { GeneChip; } \\
\text { CodeLink; Stanford }\end{array}$ & $\begin{array}{l}\text { SNCA } \\
\text { ALAS2 } \\
\text { FECH } \\
\text { BLVRB }\end{array}$ & $\mathrm{HC}$ & $\begin{array}{l}{[2]} \\
\text { Scherzer and } \\
\text { colleagues } 2008\end{array}$ \\
\hline & Whole blood & $\begin{array}{l}\text { Affymetrix U133A } \\
\text { GeneChip }\end{array}$ & $\begin{array}{l}\text { SNCA } \\
\text { DBH } \\
\text { ST13 }\end{array}$ & Sporadic & [16] \\
\hline & PBMC & $\begin{array}{l}\text { Semi-quantitative } \\
\text { PCR }\end{array}$ & $\begin{array}{l}\text { MIP-1 alpha } \\
\text { MCP-1 } \\
\text { IL-8 } \\
\text { IL-1 beta } \\
\text { IFN gama } \\
\text { TNF alpha }\end{array}$ & Sporadic & [17] \\
\hline & Whole blood & qRT-PCR & $\begin{array}{l}\text { PSMA2-5 } \\
\text { LAMB2 } \\
\text { ALDH1A } \\
\text { HIP2 } \\
\text { HIST1H3E }\end{array}$ & Sporadic & [6] \\
\hline & lymphocytes & qRT-PCR & $A_{2 A} A R$ & Sporadic & [11] \\
\hline
\end{tabular}




\begin{tabular}{|c|c|c|c|c|c|}
\hline Samples origin & $\begin{array}{l}\text { Region /cell } \\
\text { type }\end{array}$ & $\begin{array}{l}\text { Method of } \\
\text { measurements }\end{array}$ & Genes found & $\begin{array}{l}\text { Familial / } \\
\text { Sporadic PD / } \\
\text { HC }\end{array}$ & $\begin{array}{l}\text { Reference / the } \\
\text { research group }\end{array}$ \\
\hline & Whole blood & $\begin{array}{l}\text { Affymetrix } \\
\text { Exon_ST1 }\end{array}$ & SRRM2 long isoform & Sporadic & [12] \\
\hline & PBMC & $\begin{array}{l}\text { Agilent one-colour } \\
\text { whole human } \\
\text { genome } 44 \mathrm{~K} \\
\text { microarray; } \\
\text { Genotyping }\end{array}$ & $\begin{array}{l}\text { ALAS2, } \\
\text { ARG1 } \\
\text { DUSP10 } \\
\text { ERAF } \\
\text { IFNG } \\
\text { LTF } \\
\text { SELENBP1 } \\
\text { UTG2B17 }\end{array}$ & $\begin{array}{l}\text { PD carriers of } \\
\text { LRRK2 mutation }\end{array}$ & $\begin{array}{l}{[18]} \\
\text { Mutez and } \\
\text { colleagues } 2010\end{array}$ \\
\hline & Whole blood & $\begin{array}{l}\text { Affymetrix Human } \\
\text { Gene } 1.0 \text { st. }\end{array}$ & TRIM24 & $\begin{array}{l}\text { Sporadic; } \\
\text { PARK2, PARK8 }\end{array}$ & [19] \\
\hline & leukocytes & $\begin{array}{l}\text { qRT-PCR; } \\
\text { comparative } \\
\text { genomic } \\
\text { hybridization; one- } \\
\text { color whole human } \\
\text { genome 44K } \\
\text { microarrays }\end{array}$ & $\begin{array}{l}\text { SNCA } \\
\text { FAM13A }\end{array}$ & $\begin{array}{l}\text { Familial with } \\
\text { SNCA } \\
\text { duplication }\end{array}$ & [18] \\
\hline
\end{tabular}

Annotation: $A_{2 A} A R$, adenosine $2 A$ receptor; $A L A S 2$, 5-aminolevulinate synthase 2; ALDH1A1, aldehyde dehydrogenase 1 family member A1; ANP32B, acidic (leucine-rich) nuclear phosphoprotein 32; ARG1, arginase, liver; BA9, Brodmann's Area 9; BLVRB, biliverdin reductase B; CLTB, clathrin, light chain B; CNS, central nervous system; D3R, dopamine receptor D3; DA, dopaminergic; DBH, dopamine beta-hydroxylase; DJ-1, PARK7; DNAJB5, DnaJ (Hsp40) homologue, subfamily B, member 5; DUSP10, dual specificity phosphatase 10; ENO2, neuron-specific enolase; ERAF, Erythroid associated factor; FAM13A, family with sequence similarity 13 , member $\mathrm{A}$; FECH, ferochelatase; FGF13, fibroblast growth factor 13; GBE1, Glucan $(1,4-\alpha-)$, branching enzyme 1 (glucagen branching enzyme, Andersen disease, glycogen storage disease type IV); HC, healthy controls; GAD67, glutamic acid decarboxylase 67kDa isoform; HIP2, huntigntin interacting protein 2 (PARK5); HIST1H3E, histone cluster-1 H3e; HSPA1A-B, heat shock protein A1A-B; HSPA8, Heat shock protein A8; HSPB1, heat shock 27 kDa protein 1; HTR2C, 5-hyproxytryptamine (serotonin) receptor 2C; IFNG, Interferon gamma; IR, insulin receptor, LAMB2, laminin, beta-2 (laminin S); LB, Lewy Bodies; LTF, 
Lactotransferrin; MRPS6, mitochondrial ribosomal protein S6; NEFL, neurofilament, light polypeptide; NM, neuromelanin; NPY, neuropeptide Y; NSF, N-ethyl maleimide-sensitive factor; PBMC, peripheral blood momonuclear cells; PD, Parkinson's disease; PGC-1a, proliferator-activated receptor gama coactivator-1alpha PINK1, PTEN induced putative kinase 1 (PARK6); PSMA2-5, proteasome subunit alpha type 2-5; PSMB4-5/C3/D4, proteasome (prosome, macropain) subunit beta type 4-5/ $26 \mathrm{~S}$ subunit ATPase3/ non-ATPase 4; qRT-PCR, quantitative RT-PCR; SELENBP1, Selenium binding protein 1; SEPT4, septin 4; SKP1A, S-phase kinase-associated protein 1A (p19A); SN, substantia nigra; SNAP25, synaptosomal-assocoated protein; SNCA, Alpha-synuclein (PARK1); SOD1, superoxide disomutase 1; SRRM2, serine/arginine repetitive matrix 2; ST13, suppression of tumorigenicity 13; STCH, stress 70 protein chaperone; STIP1, stress-induced phosphoprotein 1 (Hsp 70/Hsp90-organizing protein); STX1A, syntaxin 1A; SYN1-2. synapsin 1-2; SYT1, synaptotagmin 1, TH, tyrosine hydroxylase; TRIM24, tripartite motif containing 24; UBE1, ubiquitin-activating enzyme E1 UCHL-1, ubiquitin C-terminal hydrolase (PARK5); UQCRC2, Ubiquinol-cytochrome c reductase core protein II; USP8, ubiquitin specific protease 8; UTG2B17, UDP glucuronosyl transferase 2, B17; 